\title{
Exploitation Strategy and Performance of Contract Manufacturing Exporters: The Mediating Roles of Exploration Strategy and Marketing Capability
}

\begin{abstract}
Contract manufacturing exporters (CMEs) receive a meagre share of global value chain returns, primarily because of the mundane and exploitative nature of the activities they perform in their dependency relationships with lead firms. We posit that CMEs can enhance their performance by capitalizing on their exploitation strategy. Exploitation strategy triggers exploration strategy which requires building marketing capabilities for enhanced performance. Based on data from 154 Vietnamese CMEs, we find significant indirect only mediation effects of: 1) exploration strategy between exploitation strategy and export performance; and 2) marketing capability between exploration strategy and export performance. Further, we find significant indirect only serial mediation of exploration strategy and marketing capability between exploitation strategy and export performance. The findings are also supported and contextualized based on illustrative quotes from face to face semi-structured interviews with senior managers of 10 Vietnamese CMEs. The findings suggest that CMEs' that consciously capitalize on the exploitation strategy by seeking exploration opportunities while building their marketing capability exhibit enhanced performance.
\end{abstract}

Keywords: Contract manufacturing exporters, Global value chains, Exploitation strategy, Exploration strategy, Marketing capability, Export performance, Vietnam

\section{Please cite this paper as:}

Sharma, R. R., Nguyen, T. K., \& Crick, D. (2018). Exploitation strategy and performance of contract manufacturing exporters: The mediating roles of exploration strategy and marketing capability. Journal of International Management, 24(3), 271-283. doi:https://doi.org/10.1016/j.intman.2018.02.001 


\section{Introduction}

Contract manufacturing exporters (CMEs) play a significant role in the global economy. Exports by CMEs account for over half of the global trade in non-fuel goods (Gereffi and Lee, 2012; WTO, 2011). They are typically located in developing countries and produce and export goods according to a lead firm's specifications. CMEs receive orders from lead firms, run production and subsequently export goods following the lead firms' specifications (Buckley, 2009; Gereffi, Humphrey and Sturgeon, 2005). Understanding the performance and behaviors of CMEs, which are the supply side of international outsourcing relationships, is important as they are strategic players in such relationships and their success or failure is likely to impact value chain effectiveness.

Although participating in global value chains is widely recognized as a mode of fast access to the international market for CMEs (Buckley, 2009; He and Wei, 2013), their share in value chain returns is meager primarily because of their low bargaining power and the mundane nature of the activities they perform (Dedrick, Kraemer and Linden, 2010; Lavie, 2007; Shin, Kraemer and Dedrick, 2012). CMEs' low bargaining power results from their dependence on lead firm's resources while their own resources are much less needed by the lead firm (Casciaro and Piskorski, 2005). CMEs are not scarce and lead firms have the options to switch to other suppliers which again increases the CME's dependency on the lead firms (Lippman and Rumelt, 2003). Moreover, their activities are mundane and exploitative in the sense that they manufacture as per the lead firm's specifications and have little opportunity to explore beyond the given specifications (Buckley, 2009; Gereffi et al., 2005). So, the question arises as to how CMEs can enhance their performance. The answer lies in capitalizing on their exploitation strategy. In summary, we posit that exploitation strategy triggers exploration strategy which requires building marketing capabilities for enhanced performance. 
Exploitation strategy relates to competition-based activities to exploit current capabilities and knowledge while exploration strategy implies entrepreneurship behavior driven by risk-taking activities to explore new competencies and opportunities (Hitt et al., 2011). Examples of exploitation strategy for CMEs include leveraging existing capabilities such as manufacturing their existing products with more efficiency through process upgrading which includes improvement in machinery and production capability. Exploration strategy, on the other hand, includes both product and functional upgrading. Product upgrading is making new or higher value added products while functional upgrading is moving up the value chain. Adding value to existing products for current buyers or modifying current products to sell them to new markets are the examples of exploration strategy.

We borrow insights from the resource dependency theory and the ambidexterity organization hypothesis to explain how CMEs can capitalize on their exploitation strategy to enhance their performance. The ambidexterity hypothesis argue that though path dependencies favor choosing only one strategy based on their experience and learning, firms strive to balance both the exploratory and exploitative activities in the long run (Lavie and Rosenkopf, 2006; O'Reilly and Tushman, 2004). On the other hand, the resource dependency theory suggests that firms aim to reduce the uncertainty and power imbalance which arises because of dependency relationships (Pfeffer and Salancik, 2003). CMEs are weaker firms in their power asymmetric relationships with the lead firms. They need to manage this dependency to enhance their performance. Since firms need to balance exploitation and exploration activities for sustained performance (Raisch et al., 2009) and CMEs typically engage more in exploitation activities, their next course of action becomes exploratory activities. Thus, CMEs' existing exploitation strategy is likely to trigger their exploratory entrepreneurial behavior.

CMEs move to exploration activities to use a dual strategy whereby they simultaneously interact with the resource-rich partner (Gras and Mendoza-Abarca, 2014; Su, 
Mao and Jarvenpaa, 2014) while pursuing entrepreneurship or searching for new market opportunities outside of the current dyad (Casciaro and Piskorski, 2005). Thus, they just don't rely on exploitation strategy, being insufficient for the wealth creation, as it can co-exist with exploration strategy (Sirén, Kohtamäki and Kuckertz, 2012). Research shows that simultaneously adopting exploitative and exploratory behaviors benefits firm performance (Shirokova, Vega and Sokolova, 2013; Sirén et al., 2012). Part of the positive effect of this duality on performance has been suggested to stem from its ability to transform a firm's resource base (Kuratko, Hornsby and Hayton, 2015). The resource base considered in this study is the marketing capability of CMEs. Although transforming the resource base is one of the key purposes of the dual pursuit of exploitation and exploration strategies (Hitt et al., 2011; Kuratko et al., 2015) the examination of how these two strategies enhance a firm's long-term viability through resource transformation is still limited (Vandaie and Zaheer, 2014; Yu and Sharma, 2016).

We contribute by enhancing the understanding of how CMEs can capitalize on their exploitation strategy to enhance performance: by undertaking exploration activities and transforming resources i.e. marketing capability. Sirén et al. (2012) note that exploitation and exploration strategies do not fully explain performance because of the existence of mediators. They examined the mediating effects of strategic learning. We add to the literature by examining another mediator, marketing capability, which is relevant for the CMEs under investigation. Marketing capabity is a strategic resource that has been found to have significant influence on firm performance (Krasnikov and Jayachandran, 2008). Moreover, the current literature examines the balancing and moderation effects of exploitation and exploration strategy (Dunlap-Hinkler, Kotabe and Mudambi, 2010; Raisch and Birkinshaw, 2008; Raisch et al., 2009; Sirén et al., 2012). We suggest the 'mechanism' or mediation effects of exploration strategy. We argue that CMEs' move to exploratory activities is triggered by their exploitation 
activities. In other words, exploitation strategy by itself is not sufficient, rather it is the exploration strategy and enhanced marketing capability that explains their superior performance. Thus, we suggest that an alignment between competitive behavior (exploitation strategy) and entrepreneurial behavior (exploration strategy) can transform firms' strategic resources to superior performance. We contribute by examining the combined impact of the three behaviors: competitive behavior (exploitation strategy), entrepreneurial behavior (exploration strategy) and resource transformation.

The remainder of the paper is organized as follows. The next section builds the theoretical model which is followed by a section on hypotheses development. Then the methodology used and analysis results are presented. The last section presents discussion and conclusions including theoretical and managerial implications and limitations of the study.

\section{Theoretical model}

We theoretically propose (Figure 1) that CMEs can enhance their performance by capitalizing on their exploitation strategy and shifting their strategic direction through unilateral strategies and building related capabilities. We further argue that the other option of restructuring activities through bilateral tactics is not preferred by CMEs. While adopting unilateral tactics, CMEs are leveraging their current exploitation activities with the lead firms. This results in their enhanced performance.

\section{Insert Figures 1 about here}

The proposed theoretical model primarily draws from the resource dependence theory and ambidextrous organization hypothesis. The resource dependency theory assumes that firms do not possess sufficient resources and capabilities and thus seek complementary resources from the external environment to achieve their strategic goals (Hillman, Withers and Collins, 2009; Pfeffer and Salancik, 2003). This leads to dependence on other organizations as well as uncertainty of resource access and utility. The extent of dependence depends on the importance 
of resources to the firm, its ability to control those resources, and the autonomy of resources allocation and usage (Pfeffer and Salancik, 2003). The more a firm's valued resources are controlled by the external environment, the more it depends on other organizations to overcome resource constraints. Further, the theory assumes that the purpose of organizations is to reduce uncertainty and power of the other party over them. The theory posits that firms interact with the external environment in a way to minimize dependency and maximize autonomy in dealing with resource constraints. A central focus of the theory is to explain the motivation and actions organizations can take to manage uncertainty and dependence on exchange partners (Davis and Cobb, 2010). CMEs largely depend upon the resources of lead firms and thus have little autonomy to pursue their own ambitions.

One of the options open to resource dependent firms such as CMEs is to restructure activities to ensure resource access, and to strive for autonomy (Casciaro and Piskorski, 2005; Pfeffer and Salancik, 2003). The tactics available are primarily bilateral and require interaction with a powerful party such as the lead firms (Davis and Cobb, 2010; Hillman et al., 2009). However, these bilateral tactics are hard for resource dependent firms to achieve. The powerful firm, because of its dominance, is in a better position to impose its will on the powerdisadvantaged counterpart and is unlikely to support the inter-firm dependence restructuring plan (Lee, Mun and Park, 2015). Therefore, weaker firms are not able to get consent from their power leading partner and need to pursue unilateral strategies for dependence restructuring activities (Casciaro and Piskorski, 2005).

Unilateral strategies conducted by the less powerful firm involve a shift in strategic direction such as market diversification or entrepreneurship. As of unilateral strategies, weaker firms have been observed to shift the focus of their exchange activities away from the powerful party while continuing to work with powerful partners (Gras and Mendoza-Abarca, 2014; Su et al., 2014) because they are in need of resources owned by them. Exiting lead firms is not a 
viable option for CMEs as they would lose reliable and stable income coming from the lead firms (Murphree and Anderson, 2017). As a result, the weaker firm does not discontinue interaction with the power leading firm and unilateral strategies are used as part of its course of actions to reduce dependency. Thus by adopting unilateral strategies, weaker firms can target other externals for their dependence restructuring activities (Casciaro and Piskorski, 2005).

This use of dual strategy where weaker firms simultaneously interact with the resourcerich partner while pursuing entrepreneurship or searching for new market opportunities outside of the current dyad aligns with the ambidextrous organization hypothesis which calls for balancing both exploitative and exploratory activities (O'Reilly and Tushman, 2004; Stettner and Lavie, 2014). Weaker firms can succeed by enhancing the value of resources and capabilities under their control rather than focusing on engaging in inter-organizational arrangements (Choudhury and Khanna, 2014). As CMEs initially engage in exploitation activities, they can balance these by undertaking unilateral exploration activities to reduce their dependency with the lead firm. Though the path dependency argues for use of more of the same strategy, undertaking unilateral exploratory activities is more likely as it enable CMEs to balance exploitation and exploratory activities in the long run (Lavie and Rosenkopf, 2006).

When CMEs start engaging in exploration activities in addition to exploitation activities, they need to focus on resource transformation (Madhok and Keyhani, 2012; Simsek and Heavey, 2011). The idea that weaker firms can enhance the value of their resources also suggests a solution whereby weaker firms pay more attention to their internal resource base. Among firm internal resources, the most frequent driver of firm performance is firm capability, which is defined as a firm's ability to deploy its resources "to effect a desired end" (Amit and Schoemaker, 1993 p. 35). The positive impact of building related capabilities on firm performance is well accepted in the literature (Krasnikov and Jayachandran, 2008). 
In the light of the proposed theoretical model, we contend that to improve performance CMEs capialize on their exploitation strategy to move on to explore entreprenurial opportunities while building related capabilites. For example NhaBe Corporation (https://www.nhabe.com.vn/eng/), a Vitenamese CME, was using exploitation strategy from $1992-2008$ when it was mainly engaging in assembly work. In 2005, it started exploring other opportunites and increased its investment in machinery. From 2008 onwards it invested in improving marketing capabilities, and launching new products in domestic markets. It started exporting these in 2015. Meanwhile the firm continued to carry out assembly work as well. Its export sales increased substantially during this time: \$1.6 million in 1992 to $\$ 90$ million in 2008 and $\$ 200$ million in 2015. The firm's exports constituted 95\% of its total revenue. Simialrily, An Phuoc Group (http://www.anphuoc.com.vn/) began with assembly work in 1993 and in 1997 began to explore other export markets such as the USA and Germany. Over time, it has moved from just being an assembler to selling its own branded products.

While arguing for building related capabilites, we focus on marketing capabilites. Krasnikov and Jayachandran (2008) in a meta-analysis of 114 tests on the relationship between firm capabilities and performance found that marketing capability had the strongest influence on performance among organizational capabilities frequently studied in existing literature. Moreover, when CMEs move on to marketing their own new and or adapted products to new markets, building marketing capability is essential. Marketing capability refers to a firm's set of skills and its knowledge of a market and customer needs as well as to a firm's ability to forecast and respond to those needs (Day, 1994; Song, Nason and Di Benedetto, 2008; Zou, Fang and Zhao, 2003). Marketing capability helps a firm to respond to market requirements and to anticipate changes in market conditions (Day, 1994). It thus helps to secure the firm's market position (Song et al., 2008), and to build innovation-based competitive advantage (Mariadoss, Tansuhaj and Mouri, 2011). 


\section{Hypotheses development}

Based on the theoretical model discussed above, we hypothesize that exploitation strategy contributes to CMEs' performance in general. However, this relationship is mediated by their exploration strategy and marketing capability. These hypotheses are articulated below.

\subsection{Exploitation strategy and performance}

Exploitation strategy focuses on the refinement and improvement of firm advantages for deeper penetration into an existing customer base. Research suggests that in interfirm relationships, performance for the members depends on both the value created and their ability to claim their shares of value created by joint actions (Wathne and Heide, 2000). CMEs can achieve value creation by improving production efficiencies by exploiting their current strengths and abilities. CMEs' improvement of ongoing operational competences is valued by lead firms which to some extent reduces the power gap and dependency and thus their ability to appropriate a larger share of the pie (Kim and Wemmerloev, 2015; Lavie, 2006). This is because the lead firm would gain in the long run by nurturing the value creation potential of CMEs. By increasing their efficiencies and creating value, CMEs increase the need of the lead firms to maintain supply relationships. Thus, CMEs enhance their performance by higher value creation and appropriation made feasible through improvements in operational skills and wider accessibility to lead firms' resources. CMEs are able to have steady and stable revenues by supplying manufactured goods to their lead firms. Therefore, we hypothesise that:

H1: Exploitation strategy is positively associated with the performance of CMEs.

\subsection{The mediating role of exploration strategy}

In the case of power asymmetric relationships such as CMEs and their lead firms, value distribution among alliance members is distorted unfavorably for the weaker firm (Lavie, 2006). Because the dominant party can extract the lion's share of the value created from collaborative activities (Kim and Wemmerloev, 2015), weaker firms are likely to be 
dissatisfied with the earnings they generate from the joint activities (Gilliland and Kim, 2014). Dissatisfaction with economic gains from the current activities can motivate the weaker firm to pursue innovative efforts for new streams of value (Alvarez and Barney, 2001). As a result, it is likely to invest in developing new strategic resources for additional sources of value.

Moreover, an unbalanced relationship often entails high dependence of the weaker firm on the dominant partner. This dominance can force the former to adopt practices imposed by the latter (Hoejmose, Grosvold and Millington, 2013). Apart from the adoption of practices that enhance relational factors for long-term relationships (Cox, 2001; Xiao, Xie and Hu, 2013), there are also requirements from the dominant firm that cause risks, ambiguity, instability, and high costs for the weak firm (Touboulic, Chicksand and Walker, 2014). To mitigate these negative influences caused by demands from the dominant party, firms on the weaker side often strive for ways to restructure dependency and generate new income. Diversification by looking for other alliances or expanding the market base is a common strategy (Ciabuschi, Holm and Martin, 2014; Gras and Mendoza-Abarca, 2014; Su et al., 2014). This expansion reflects an exploration path practiced by CMEs.

Exploration practices entail penetration into a different market/product matrix. This strategy can be done either by selling products or services into markets outside of the existing network (Prashantham and Birkinshaw, 2008), or by adding more value into product attributes currently created in network activities (Lahiri and Kedia, 2009; Zimmermann, Raisch and Birkinshaw, 2015). When diversifying into new markets, entrepreneurial practices can be less risky for weaker firms. The ongoing relationship with the powerful partner offers them an opportunity to quickly modify existing products to tap into a different market (Navas-Alemán, 2011; Su et al., 2014). Because of this by-product effect of the relationship, they are able to skip product development processes which can be costly to other firms. Therefore, product 
knowledge learned from established relationships can help reduce the firm's entry costs into new market segments (Speckbacher, Neumann and Hoffmann, 2015).

In order to improve product attributes, product development processes are often undertaken during the dyadic collaboration between the two parties (Kotabe, Martin and Domoto, 2003; Oh and Rhee, 2008; Zimmermann et al., 2015). External resources attained through collaborative actions can also mitigate risks and surpass high costs inherent to opportunity-seeking activities (He and Wei, 2013; Song et al., 2008). As a consequence, this support allows the weak firm to strengthen its products in a less costly way than firms that do it alone. Moreover, engaging in exploration activities which are triggered by exploitation activities results in reduced dependency and thus relatively higher power for weaker firms such as CMEs. CMEs are likely to improve their performance by enriching the activities they perform and making use of their relatively improved bargaining power. Thus we hypothesize that:

Hypothesis 2: Exploration strategy mediates the relationship between exploitation strategy and the performance of CMEs.

\subsection{The mediation role of marketing capability}

Marketing capability can be regarded as a strategic resource as it is distinct for each firm (Song et al., 2008), adds to value by coordinating resources (Day, 1994), and has tacit, path dependent, and a causally ambiguous nature (Krasnikov and Jayachandran, 2008). Marketing capability is an important driver of firm performance as it strengthens a firm's ability to capture market opportunities (Zou et al., 2003) and attain desirable outcomes (Mariadoss et al., 2011). Marketing capability is found to enhance performance (Morgan, Katsikeas and Vorhies, 2012; Vorhies, Morgan and Autry, 2009).

While expanding into new markets or offering new products/services, it is necessary for the firm to enhance its knowledge of markets (O'Cass, Ngo and Siahtiri, 2015). Exploration 
strategy is related to innovation-based activities that center on either expansion to new markets which rely less on existing network-based business (Prashantham and Birkinshaw, 2008; Su et al., 2014), or on offering new products/services for ongoing joint activities (Lahiri and Kedia, 2009; Zimmermann et al., 2015). In addition, when implementing innovation-based strategies, it becomes necessary for the firm to implement task-specific marketing skills related to targeting customers, setting prices, or building relationships with customers and other channel members (Mariadoss et al., 2011). This necessity makes the development of marketing capability likely because firms tend to improve organizational processes and competitive capability critical for the pursuit of exploratory objectives (Lisboa, Skarmeas and Lages, 2011; Simsek and Heavey, 2011; Weerawardena, 2003).

Marketing capability is likely to transform CMEs' exploration strategy into improved performance. Pursuing exploration strategy without building marketing capability hinders a firm's growth as the development of new products or venturing into new markets requires market understanding. As a dynamic capability it supports other resources or capabilities (exploration strategy) in adding value to the firm (Teece, 2014). Capabilities enhance value creation activities as they represent organizational knowledge and processes that serve to deploy resources in a more effective manner (Day, 1994). Increased competence through improved bundles of skills and capability allows weaker firms to better create value in the interfirm relationships (Zimmermann et al., 2015). CMEs can enhance their performance through the development of their internal capability. As a result, the development of CMEs' marketing capability is also likely to contribute toward their performance. Thus, entrepreneurial activities (exploration strategy) translate to performance through their ability to improve a firm's internal resource base, especially of a firm's marketing capability (Weerawardena, 2003). Based on the above arguments we hypothesize that: 
Hypothesis 3: Marketing capability mediates the relationship between exploration strategy and the performance of CMEs.

From the above three proposed hypotheses, it can be advanced that exploitation strategy impacts the performance of CMEs through exploration strategy and marketing capability. Due to the influential role of the dominant firm in the relationship, entrepreneurial activities by weaker firms are most likely to capitalize on their existing activities. The pursuit of exploration strategy encourages the development of marketing capability as a strategic resource that is necessary to facilitate either market expansion or product improvement strategies. Thus, we hypothesize that:

H4: Exploration strategy and marketing capability mediate the relationship between exploitation strategy and the performance of CMEs.

To summarize, we propose the role of the alignment between exploitation and exploration strategy to leverage marketing capability in enhancing performance. In other words, exploitation strategy by itself is not sufficient for these effects. However, they occur because of exploration strategy and the marketing capability of CMEs.

\section{Methodology}

\subsection{Data}

The data was collected via a survey in 2014 in Ho Chi Minh City, Dong Nai, and Binh Duong provinces of Vietnam. We chose Vietnam as our research context for two reasons. The majority of the country's export sales is attributed to a large number of CMEs' that process products under international designs and brands (Goto, Natsuda and Thoburn, 2011; Vixathep and Matsunaga, 2012). Although Vietnam is second to China on contract manufacturing, the country is becoming more attractive as a favorable offshoring location due to the trend of shifting production from coastal China to other low-cost locations (Gereffi, 2011; Nadvi et al., 
2004). The chosen three areas host a large number of CMEs in the targeted industries: garment, footwear and wood furniture industries (Mahutga, 2013). These three industries are the country's leading exporting industries with a $26 \%$ share of total exports.

Data collection in Vietnam can be difficult as businesses are hesitant to disclose business information and many managers feel uncomfortable when asked about their business. Therefore, our sample was selected based on managers' willingness to cooperate as suggested for research practices in Vietnam (De Jong, Tu and Van Ees, 2012). We recruited staff from trade support institutions and industry associations who helped develop a list of potential respondents based on their existing network and later distributed the survey. Social networks from affiliated organizations have been shown to be effective in gaining executive trust and willingness for survey participation (Cycyota and Harrison, 2006). Firms not satisfying the criterion of being CMEs in the three targeted industries were deleted, resulting in 175 targeted respondents.

We followed the drop-and-collect method to collect data (Ibeh, Brock and Zhou, 2004). Surveys could be collected immediately depending on the availability and willingness of the respondents, otherwise a reminder and pick-up notification was issued a week later before a personal pick-up in the following three days. We targeted managers from top management teams or exporting manager, in line with other studies in the exporting field (Morgan et al., 2012; Zou et al., 2003). Data was obtained from 167 respondents out of a total 175 managers asked to participate. In total, 154 surveys were used for subsequent analysis, resulting in an $88 \%$ usable response rate. The sample consisted of CMEs in garment (54.5\%), wood furniture (30.5\%) and footwear (14.9\%) industries. Almost one third of the sample was small- and medium- sized firms, the rest being large firms. Four-fifths of the sample CMEs were serving both the home and foreign market while rest were serving foreign markets only. 


\subsection{Measurement}

Because CMEs manufacture and export products according to specifications given by the lead firm (Buckley, 2009; Gereffi et al., 2005), a CMEs' performance is measured as its export performance. Moreover, because of the nature of their operations, most of the revenue of CMEs come from their exporting activities. Measurement items for each of the scale are shown in Table 1. Export performance is measured as the senior managers' rating of their export performance for the last year. The items are borrowed from Katsikeas, Leonidou and Morgan (2000). Exploitation and exploration strategy items are borrowed from Sirén et al. (2012) and marketing capability items from Song et al. (2008).

The subjective assessment of export performance encourages managers' responses and allows detailed inquiries on managers' application and interpretation of export performance criteria (Leonidou, Katsikeas and Samiee, 2002). Besides, subjective measures have been found to be positively correlated with objective data (Wall et al., 2004) and extensively used in the exporting field (Katsikeas et al., 2000), especially in developing countries where respondents are reluctant to disclose objective figures (Brouthers and Xu, 2002). Additionally, export performance was evaluated at the firm level and for all markets. This is because CMEs have limited involvement in making decisions on products and markets since they produce and export products according to orders from international lead firms. Moreover, exploitation and exploration strategies pertain to organization-wide activities; therefore, their outcomes should also be measured at the same level (Oliveira, Cadogan and Souchon, 2012).

As of control variables, industry is recorded as 1 if a firm operates in the garment industry and 0 if it is in the footwear and furniture industries. This classification is made due to observation that most upgrading practices are observed in firms in the garment industry. Therefore, it is likely that the impact of exploration strategy can be different in the other two industries. CMEs' export experience is coded as 1 for CMEs who started their export activities 
before 1998, otherwise 0 . The cutoff point of 1998 is chosen as the country opened export activities to all forms of organizations in 1998. In Vietnam, small-and-medium-size firms are defined as firms with number of workers less than 300. Therefore, firm size is coded as 0 for small and medium firms, and as 1 for large with at least 300 workers. Market operation was recorded as 1 for firms having businesses in both export and domestic markets, and 0 for firms with only exporting operations.

\subsection{Contextual qualitative data}

To supplement the quantitative research findings and provide contextual details (Greene, Caracelli and Graham, 1989), we interviewed 10 CMEs (five garment, three footwear and two furniture). Out of the ten interviewees three were director/ vice-director, three president/vicepresident, and four CEOs. The semi-structured interviews were conducted face to face at the company premises and lasted about an hour each. For the purpose of this paper, we have taken illustrative quotes from these interviews to provide context and support to the study results.

\section{Analysis and results}

The partial least squares structural equation modelling (PLS-SEM) technique was employed to analyze the data. The use of PLS-SEM is appropriate with predictive and exploratory purposes (Reinartz, Haenlein and Henseler, 2009). Our study is considered more exploratory and theorybuilding in nature because relationships proposed in the model, which hypothesizes influences of exploitation-exploration strategies on firm marketing capability and performance of CMEs in asymmetric relationship, are not sufficiently examined in prior studies. Therefore, the study does not aim at confirming existing theories and its primary interest is to focus on the prediction ability of the model. The SmartPLS software version 3.0 was used to construct the measurement and structural models.

Both procedural and statistical approaches as suggested by Chang, Witteloostuijn and Eden (2010) and Podsakoff, MacKenzie and Lee (2003) are adopted to address common 
method variance (CMV). As for procedural remedy, we used different scale anchors and endpoints for predictors and criterions to reduce any possible systematic influence of scale format on responses (Tourangeau, Rips and Rasinski, 2000). Informants were assured of anonymity as information referring to names of the company and managers would not be recorded in the questionnaire. Moreover, instructions to ensure that respondents knew that there were no right or wrong answers were included to encourage honest responses.

Furthermore, the study also applied Harman's one-factor test and the use of marker variables as additional statistical techniques to address the issue of CMV. The results of the Harman one-factor test reveal 4 factors with Eigen values greater than 1. Approximately 36\% of the variance is accounted for by the first factor. A 3-item measure to identify a firm's 'brand association with a bank' (Phan and Ghantous, 2013) is included in the questionnaire as a marker variable. These items are chosen for their theoretical un-relatedness to the main proposed constructs and the way to measure them is similar to that applied to the dependent variables (Williams, Hartman and Cavazotte, 2010). Conceptually, association pertains to psychocognition processes (Keller, 1993) that could affect a firm's social association with a bank such as loyalty and relationships (Phan and Ghantous, 2013) rather than the firm's strategy, its performance or capabilities. Further confirmation of the study being satisfactorily free from any CMV issue was drawn from analyses showing that this marker variable was not significantly linked to any focal constructs in the model and there were no considerable changes in path coefficients between two cases when the market variable was controlled for and when it was excluded from the model.

\subsection{The measurement model}

Reliability and validity of the measurement model is demonstrated by the results in Tables 1 and 2. AVE values of all constructs are above .5, demonstrating that the constructs capture an adequate amount of variance observed by their corresponding items (Fornell and Larcker, 
1981). Values of all indicator loadings are above 0.6 and show that the indicators satisfactorily represent the intended constructs (Bagozzi and Yi, 1988). While item loadings demonstrate their adequacy in contributing to their respective construct, it is often of greater interest to examine how well a block of indicators jointly measures the construct adequately by means of Cronbach's $\alpha$ and composite reliability $\left(\rho_{c}\right)$. Results of Cronbach's $\alpha$ above .7 (Vinzi, Trinchera, \& Amato, 2010) and $\rho_{c}$ above .8 (Bagozzi and Yi, 1988) for all latent variables show strong mutual association among indicators in describing the intended constructs.

Discriminant validity at the construct level is examined by means of the Fornell-Larcker criteria, which compares the square root of the AVE score of each construct and correlations among constructs (Fornell and Larcker, 1981). The results in Table 2 indicates that the variance explained by indicators of each construct is greater than the shared variance between the construct and other latent variables. Discriminant validity of the study is further confirmed when assessing the heterotrait-monotrait ratio criteria (Henseler, Ringle and Sarstedt, 2015), with their values lower than 0.9 . Furthermore, the model is free from multicollinearity as all VIF values of the constructs under examination are below 3, well below the cut-off point of 5 suggested in literature (Hair, Ringle and Sarstedt, 2011).

\section{Insert Tables 1 and 2 about here}

\subsection{The structural model}

The structural model results are reported in Figure 2 and Table 3. Figure 2a tests the direct effect of exploitation strategy and Figure $2 \mathrm{~b}$ introduces exploration as a mediator. The second mediator of marketing capability is added in Figure 2c. Figure 2a shows highly significant results for exploitation strategy - export performance relationships, thus supporting H1. Figure 2b shows highly significant results for exploitation - exploration strategy and exploration strategy - export performance relationships. Further, Table 3 reveals that the mediation path is significant at a 5\% significance level; therefore, hypothesis $\mathrm{H} 2$ is accepted. 
The other two hypotheses (H3, H4) are tested using Figure 2c, which specifies exploration strategy and marketing capability as serial mediators linking exploitation strategy and performance. Highly significant results are evident for exploration strategy - marketing capability, and marketing capability - export performance relationships. Because the analysis software only reports results for the sum of mediation effects in such type of models, testing results for the individual mediation paths of this study are based on the bias-corrected bootstrapping technique using 5,000 resamples as suggested in the literature (Hayes, 2013). As can be seen from Table 3, the mediation path connecting exploration strategy and performance through marketing capability is significant at the 5\% significance level $(\beta=0.151$, CI95\% $[0.012 ; 0.230])$. Therefore, hypothesis H3 is supported. Finally, the result of the mediation path between exploitation strategy and performance through two mediators of exploration strategy and marketing capability is also significant at the 5\% significance level $(\beta=0.105$, CI95\% $[0.008 ; 0.221])$. As a result, hypothesis H4 is supported.

\section{Insert Figure 2 and Table 3 about here}

It is important to note that the direct effects corresponding to these mediation effects are all insignificant (see Figure $2 \mathrm{~b}$ and $2 \mathrm{c}$ ). This result shows that the model is unlikely to exclude meaningful mediators. In other words, the specification of exploration strategy and marketing capability as mediators to transmit the influence of exploitation strategy on performance is complete and consistent with the hypothesized framework (Zhao, Lynch Jr and Chen, 2010). The Stone-Geisser criterion $\left(Q^{2}\right)$ in both models is positive, indicating a satisfactory predictive relevance of the hypothesized models. Moreover, the significant F value in model $2 \mathrm{c}$ and highest $\mathrm{R}^{2}$ indicate that this model is better than the other two models in explaining variances in performance (Kock, 2012). The effect sizes for the significant paths (Figure 2c) show a large effect size for two paths and a small one for one path. The $\mathrm{f}^{2}$ values of $0.02,0.15$ and 0.35 represent small, medium and large effect sizes (Cohen, 1988). 
Regarding control variables, the research models reveal that both industry and market operation are positively and statistically linked to performance at small effect size. However, the models display no significant results for export experience and size.

\subsection{Supporting illustrative quotes}

Illustrative quotes from the interviewed CMEs provide context to the main findings and are presented in Table 4. The interviewed CMEs are represented as $\mathrm{C} 1, \mathrm{C} 2$, and so on to ensure the anonymity of the participants. These quotes support the proposed model. CMEs clearly agree that both exploitation and exploration strategy contribute to performance by utilizing production capacity and finding additional products and markets. C7 talks about exploitation strategy enabling stable earnings whereas $\mathrm{C} 10$ raises the point of low margins. $\mathrm{C} 1$ provides an example of how moving from men's shirts to women's clothing enhanced their profits. CMEs also raised poor earnings $(\mathrm{C} 8, \mathrm{C} 10)$ and low power $(\mathrm{C} 7)$ as a motivation to move from exploitation to exploration activities. They also believe that their entrepreneurial behavior i.e. moving to exploratory activities $(\mathrm{C} 1, \mathrm{C} 3, \mathrm{C} 4, \mathrm{C} 5, \mathrm{C} 6, \mathrm{C} 7)$ and capability development $(\mathrm{C} 1, \mathrm{C} 2$, C2, C9) helped them to enhance their performance. These quotes (Table 4) endorse the findings of the study.

\section{Insert Table 4 about here}

\section{Discussion and conclusions}

The findings supported all the proposed hypotheses. The findings suggest that exploitation strategy leads to exploration strategy which in turn transforms marketing capability into enhanced performance of CMEs. Thus the CMEs can benefit from their exploitation strategy by pursuing entrepreneurial behavior and transforming their strategic resources. 


\subsection{Theoretical implications}

Drawing insights from the resource dependency theory and ambidextrous organization hypothesis, we put forward that CMEs that are weaker in power asymmetric relationships can manage their dependency and enhance performance by having a strategic shift in their activities and by building related capabilities. The strategic shift suggested for such CMEs is undertaking unilateral exploratory activities and the capability to build is the marketing capability.

The significant mediating effects of exploration strategy in the association between exploitation strategy and performance indicate that exploration strategy is necessary to realize the value of exploitation strategy. Exploitation strategy creates opportunities for exploratory activities wherein firms innovatively add value to their existing products (Prashantham and Birkinshaw, 2008; Zimmermann et al., 2015) or capitalize on current network products to expand into new markets (Su et al., 2014). Even though these two strategies compete for organizational resources (He and Wong, 2004; O'Cass, Heirati and Ngo, 2014), their complementarity produces better organizational outcomes. Thus, these two strategies can work in tandem to drive firm performance which is in line with the 'ambidextrous organization' hypothesis (Lavie and Rosenkopf, 2006; O'Reilly and Tushman, 2004). Lavie and Rosenkopf (2006) called such exploration 'second order exploitation' where firms tend to balance exploitation and exploration activities by learning from their experience.

Further, the alignment of the two strategies of exploitation and exploration enhance performance by transforming firm resources such as marketing capability. The serial mediation effects suggest that exploitation strategy leads to practices of exploration strategy, which in turn directs firm investments to the development of marketing capability, a strategic resource that subsequently enhances the performance of weaker firms in power asymmetric relationships. This mechanism demonstrates that exploration practices serve as a channel for maneuvering the allocation of firm resources into areas that are beneficial to firm sustainable 
performance. The findings of this mechanism endorse the tenet of resource based theory which attributes firm performance to the ownership of competitive resources (Hillman et al., 2009; Pfeffer and Salancik, 2003).

In a network context, firms can choose not to invest in marketing capability because they can take advantage of the external resources provided by the strengths of other network members (O'Driscoll, Carson and Gilmore, 2000). Being engrossed in network activities, firms may face the challenge of "network myopia", where their innovation is stifled, they are likely to fall into a "competence trap", and their network involvement can eventually become redundant (O'Driscoll et al., 2000). However, successfully engaging in asymmetric relationships requires weaker firms' to capitalize on network activities by continuously seeking opportunities to add more value into existing products/services or by taking advantage of network experience to expand into new a product-market domain.

To fully reap the benefits of this opportunity-seeking behavior, it is essential that weaker firms develop their marketing capability. The enhancement of this strategic resource can be a source of sustainability for weaker firms' network participation for various reasons. Marketing capability allows weaker firms to understand and explore new markets, the need of the powerful partner and to develop better relationships with them (O'Cass et al., 2015). Increased quality in partnership with the powerful partner can help weaker firms attain better performance (Raman et al., 2013). Besides, having a competitive strength can deter the dominant party's intention to exert their power (Gulati and Sytch, 2007). Additionally, enhancing marketing capability enables weaker firms to reduce the risk of being redundant in the network as they can outperform rivals who are competing for network resources (Chen, Chen and $\mathrm{Ku}, 2012)$.

The findings also suggest a mechanism to escape from the exploitation trap. According to Sirén et al. (2012), exploitation trap is when firms focus on their existing competencies and 
products to meet the existing needs of their current clients. In such cases, firms have a competitive advantage but do not attempt to search for new opportunities. Such firms face the risk of diminishing returns when markets change. As CMEs primarily engage in exploitation activities because of their dependency relationships with lead firms, they are likely to get into the exploitation trap. CMEs can get out of this trap by leveraging on their exploitations strategy to explore entrepreneurial activities and build marketing capabilities.

\subsection{Managerial implications}

The study suggests three main managerial implications. First, existing activities that mainly draw on exploitation strategy can provide opportunities. Normally weaker firms (e.g. CMEs) are in an unfavorable position where they may find it difficult to claim their fair share in network value extraction (Adegbesan and Higgins, 2010) or their existence can even be in danger (Alvarez and Barney, 2001). Weaker firms can rectify these downsides of participating in asymmetric relationships by capitalizing on network activities and turning them into a favorable source of income. While working on network activities, weaker firms should pursue exploration strategy by seeking opportunities for future growth. Exploration strategy can either be based on adding more innovation-based value into network products (Zimmermann et al., 2015) or modifying existing network products for new customers in other market domains ( $\mathrm{Su}$ et al., 2014). Manufacturing for their lead firms affords resource-deficient CMEs in developing countries fast access to international markets (He and Wei, 2013). However, to fully take advantage of global value chains, CMEs should pursue exploratory activities. This can be done by nurturing their innovation to add more value into their current portfolio of products or services.

Secondly, when both exploration and exploitation strategies are adopted, CMEs need to develop marketing capability which may not be necessary when only exploitation strategy is pursued. Nurturing this capability provides weaker firms with a competitive strength, which 
helps them reap more benefits from network activities (O'Cass et al., 2015) and foster their competitive advantage. Marketing capability is necessary as this strategic resource is useful for enhancing firm network position (Chen et al., 2012) and contributes to firm sustainability especially in the implementation of innovation-based strategy (Weerawardena, 2003). Thus, marketing capability is a critical firm resource which needs to be in place as it is necessary for the implementation of the weak firm's exploratory strategy.

Thirdly, CMEs need to make a conscious efforts to seek exploration opportunities and build their capabilities and improve performance. The alignment between exploitation strategy and exploration strategy helps weaker firms transform resources into performance. Exploitation strategy by itself is not enough to enhance performance, rather it helps in building exploration strategy which in-turn transforms marketing capability to enhanced performance. Thus, while maintaining existing business exchanges with international lead firms (exploitation strategy), CMEs can shift the focus of their internal resource base (exploratory strategy and building marketing capability). As such, their relationships with their lead firms contain opportunities for enhancing their own resources.

\subsection{Limitations}

The findings should be interpreted carefully because of some limitations of the study which also provide future research opportunities. The context of the study is limited to the case of CMEs in labor-intensive industries which are typically engaged in exploitation activities in the beginning. CMEs manufacture as per the lead firms' specifications. The findings may not be generalizable to capital-intensive industries such as automobile, aircrafts, and heavy machinery. In these industries, the requirement of capital and advanced technology in production facilities limits the availability of such CMEs and gives the lead firms more direct control through ongoing collaborations or equity-based ownerships (Mahutga, 2012; Oh and Rhee, 2008). Though the results can be inferred for any weaker firms in power asymmetric 
relationships, the results may not be transferred directly to other forms of asymmetric relationships (e.g. alliances, subsidiaries in MNEs) where different types of capabilities (e.g. technical capability) other than marketing capability are stressed (Alvarez and Barney, 2001). Besides, the generalization of the study may also be limited by the use of cross-sectional data and nature of the sampling based on managerial willingness to participate. Moreover, countryspecific features can have an influence on explorative activities that rely on the network activities of Vietnamese firms. Accordingly, we encourage future studies to investigate the model in other value chains and asymmetric relationships. Future studies might also use longitudinal data to investigate the influence of exploitation and exploration strategies across time on overall performance including both domestic and export performance.

\subsection{Conclusions}

CMEs can leverage off their exploitation strategy and enhance their performance by pursuing exploration strategy and building their marketing capability. Pursuing exploration strategy balances their portfolio of strategic activities. In this process, building other related capabilities (e.g. marketing capability) is critical for enhancing performance. 


\section{REFERENCES}

Adegbesan, J.A., Higgins, M.J., 2010. The intra-alliance division of value created through collaboration. Strategic Management Journal 32, 187-211.

Alvarez, S.A., Barney, J., 2001. How entrepreneurial firms can benefit from alliances with large partners. The Academy of Management Executive 15, 139-148.

Amit, R., Schoemaker, P.J., 1993. Strategic assets and organizational rent. Strategic Management Journal 14, 33-46.

Bagozzi, R.P., Yi, Y., 1988. On the evaluation of structural equation models. Journal of the Academy of Marketing Science 16, 74-94.

Brouthers, L.E., Xu, K., 2002. Product stereotypes, strategy and performance satisfaction: The case of Chinese exporters. Journal of International Business Studies 33, 657-677.

Buckley, P.J., 2009. The impact of the global factory on economic development. Journal of World Business 44, 131-143.

Casciaro, T., Piskorski, M.J., 2005. Power imbalance, mutual dependence, and constraint absorption: A closer look at resource dependence theory. Administrative Science Quarterly 50, 167-199.

Chang, S.-J., Witteloostuijn, A.v., Eden, L., 2010. From the editors: Common method variance in international business research. Journal of International Business Studies 41, 178-184.

Chen, T.J., Chen, H.M., Ku, Y.H., 2012. Resource dependency and parent-subsidiary capability transfers. Journal of World Business 47, 259-266.

Choudhury, P., Khanna, T., 2014. Toward resource independence - Why state-owned entities become multinationals: An empirical study of India's public R\&D laboratories. Journal of International Business Studies 45, 943-960.

Ciabuschi, F., Holm, U., Martin, O.M., 2014. Dual embeddedness, influence and performance of innovating subsidiaries in the multinational corporation. International Business Review 23, 897-909.

Cohen, J., 1988. Statistical Power Analysis for the Behavioral Sciencies. Routledge.

Cox, A., 2001. Managing with power: Strategies for improving value appropriation from supply relationships. Journal of Supply Chain Management 37, 42-47.

Cycyota, C.S., Harrison, D.A., 2006. What (not) to expect when surveying executives: A metaanalysis of top manager response rates and techniques over time. Organizational Research Methods 9, 133-160.

Davis, G.F., Cobb, J.A., 2010. Resource dependence theory: Past and future, in: Claudia Bird Schoonhoven, Dobbin, F. (Eds.), Research in the Sociology of Organizations, pp. 21-42.

Day, G.S., 1994. The capabilities of market-driven organizations. Journal of Marketing 58, 37-52.

De Jong, G., Tu, P.A., Van Ees, H., 2012. Which entrepreneurs bribe and what do they get from it? Exploratory evidence from Vietnam. Entrepreneurship Theory and Practice 36, 323-345.

Dedrick, J., Kraemer, K.L., Linden, G., 2010. Who profits from innovation in global value chains?: a study of the iPod and notebook PCs. Industrial \& Corporate Change 19, 81-116.

Dunlap-Hinkler, D., Kotabe, M., Mudambi, R., 2010. A story of breakthrough versus incremental innovation: Corporate entrepreneurship in the global pharmaceutical industry. Strategic Entrepreneurship Journal 4, 106-127.

Fornell, C., Larcker, D.F., 1981. Evaluating structural equation models with unobservable variables and measurement error. Journal of Marketing Research 18, 39-50.

Gereffi, G., 2011. Global value chains and international competition. Antitrust Bulletin 56, 37-56.

Gereffi, G., Humphrey, J., Sturgeon, T., 2005. The governance of global value chains. Review of International Political Economy 12, 78-104.

Gereffi, G., Lee, J., 2012. Why the world suddenly cares about global supply chains. Journal of Supply Chain Management 48, 24-32.

Gilliland, D.I., Kim, S.K., 2014. When do incentives work in channels of distribution? Journal of the Academy of Marketing Science 42, 361-379.

Goto, K., Natsuda, K., Thoburn, J., 2011. Meeting the challenge of China: The Vietnamese garment industry in the post MFA era. Global Networks 11, 355-379.

Gras, D., Mendoza-Abarca, K.I., 2014. Risky business? The survival implications of exploiting commercial opportunities by nonprofits. Journal of Business Venturing 29, 392-404. 
Greene, J.C., Caracelli, V.J., Graham, W.F., 1989. Toward a conceptual framework for mixed-method evaluation designs. Educational Evaluation and Policy Analysis 11, 255-274.

Gulati, R., Sytch, M., 2007. Dependence asymmetry and joint dependence in interorganizational relationships: Effects of embeddedness on a manufacturer's performance in procurement relationships. Administrative Science Quarterly 52, 32-69.

Hair, J.F., Ringle, C.M., Sarstedt, M., 2011. PLS-SEM: Indeed a silver bullet. Journal of marketing theory and practice $19,139-152$.

Hayes, A.F., 2013. Introduction to mediation, moderation, and conditional process analysis: A regression-based approach. Guilford Press, New York, NY.

He, X., Wei, Y., 2013. Export market location decision and performance: The role of external networks and absorptive capacity. International Marketing Review 30, 559-590.

He, Z.-L., Wong, P.-K., 2004. Exploration vs. exploitation: An empirical test of the ambidexterity hypothesis. Organization Science 15, 481-494.

Henseler, J., Ringle, C.M., Sarstedt, M., 2015. A new criterion for assessing discriminant validity in variance-based structural equation modeling. Journal of the Academy of Marketing Science 43, 115-135.

Hillman, A.J., Withers, M.C., Collins, B.J., 2009. Resource dependence theory: A review. Journal of Management 35, 1404-1427.

Hitt, M.A., Ireland, R.D., Sirmon, D.G., Trahms, C.A., 2011. Strategic entrepreneurship: Creating calue for individuals, organizations, and society. Academy of Management Perspectives 25, $57-75$.

Hoejmose, S., Grosvold, J., Millington, A., 2013. Socially responsible supply chains: Power asymmetries and joint dependence. Supply Chain Management-an International Journal 18, 277-291.

Ibeh, K., Brock, J.K.-U., Zhou, Y.J., 2004. The drop and collect survey among industrial populations: theory and empirical evidence. Industrial Marketing Management 33, 155-165.

Katsikeas, C.S., Leonidou, L.C., Morgan, N.A., 2000. Firm-level export performance assessment: Review, evaluation, and development. Academy of Marketing Science. Journal 28, 493-511.

Keller, K.L., 1993. Conceptualizing, measuring, and managing customer-based brand equity. Journal of Marketing 57, 1-22.

Kim, Y.H., Wemmerloev, U., 2015. Does a supplier's operational competence translate into financial performance? An empirical analysis of supplier-customer relationships. Decision Sciences 46, 101-134.

Kock, N., 2012. WarpPLS3.0 User Manual. Script Warp Systems, Laredo, Texas.

Kotabe, M., Martin, X., Domoto, H., 2003. Gaining from vertical partnerships: Knowledge transfer, relationship duration, and supplier performance improvement in the U.S. and Japanese automotive industries. Strategic Management Journal 24, 293-316.

Krasnikov, A., Jayachandran, S., 2008. The relative impact of marketing, research-and-development, and operations capabilities on firm performance. Journal of Marketing 72, 1-11.

Kuratko, D.F., Hornsby, J.S., Hayton, J., 2015. Corporate entrepreneurship: The innovative challenge for a new global economic reality. Small Business Economics 45, 245-253.

Lahiri, S., Kedia, B., 2009. The effects of internal resources and partnership quality on firm performance: An examination of Indian BPO providers. Journal of International Management $15,209-224$.

Lavie, D., 2006. The competitive advantage of interconnected firms: An extension of the resourcebased view. Academy of Management Review 31, 638-658.

Lavie, D., 2007. Alliance portfolios and firm performance: A study of value creation and appropriation in the U.S. software industry. Strategic Management Journal 28, 1187-1212.

Lavie, D., Rosenkopf, L., 2006. Balancing exploration and exploitation in alliance formation Academy of Management Journal 49, 797-818.

Lee, S.H., Mun, H.J., Park, K.M., 2015. When is dependence on other organizations burdensome? The effect of asymmetric dependence on internet firm failure. Strategic Management Journal 36, 2058-2074.

Leonidou, L.C., Katsikeas, C.S., Samiee, S., 2002. Marketing strategy determinants of export performance: A meta-analysis. Journal of Business Research 55, 51-67. 
Lippman, S.A., Rumelt, R.P., 2003. A bargaining perspective on resource advantage. Strategic Management Journal 24, 1069-1086.

Lisboa, A., Skarmeas, D., Lages, C., 2011. Entrepreneurial orientation, exploitative and explorative capabilities, and performance outcomes in export markets: A resource-based approach. Industrial Marketing Management 40, 1274-1284.

Madhok, A., Keyhani, M., 2012. Acquisitions as entrepreneurship: asymmetries, opportunities, and the internationalization of multinationals from emerging economies. Global Strategy Journal 2, 26-40.

Mahutga, M.C., 2012. When do value chains go global? A theory of the spatialization of global value chains. Global Networks 12, 1-21.

Mahutga, M.C., 2013. Global models of networked organization, the positional power of nations and economic development. Review of International Political Economy 21, 157-194.

Mariadoss, B.J., Tansuhaj, P.S., Mouri, N., 2011. Marketing capabilities and innovation-based strategies for environmental sustainability: An exploratory investigation of B2B firms. Industrial Marketing Management 40, 1305-1318.

Morgan, N., Katsikeas, C., Vorhies, D., 2012. Export marketing strategy implementation, export marketing capabilities, and export venture performance. Journal of the Academy of Marketing Science 40, 271-289.

Murphree, M., Anderson, J., 2017. Counting overseas power in global value chains: Information asymmetries and subcontracting in the plastics industry. Journal of International Management http://dx.doi.org/10.1016/j.intman.2017.09.007.

Nadvi, K., Thoburn, J.T., Thang, B.T., Ha, N.T.T., Hoa, N.T., Le, D.H., Armas, E.B.D., 2004. Vietnam in the global garment and textile value chain: Impacts on firms and workers. Journal of International Development 16, 111-123.

Navas-Alemán, L., 2011. The impact of operating in multiple value chains for upgrading: The case of the Brazilian furniture and footwear industries. World Development 39, 1386-1397.

O'Cass, A., Heirati, N., Ngo, L.V., 2014. Achieving new product success via the synchronization of exploration and exploitation across multiple levels and functional areas. Industrial Marketing Management 43, 862-872.

O'Cass, A., Ngo, L.V., Siahtiri, V., 2015. Marketing resource-capability complementarity and firm performance in B2B firms. Journal of Business \& Industrial Marketing 30, 194-207.

O'Driscoll, A., Carson, D., Gilmore, A., 2000. Developing marketing competence and managing in networks: A strategic perspective. Journal of Strategic Marketing 8, 183-196.

O'Reilly, C.A., Tushman, M.L., 2004. The ambidextrous organization. Harvard Business Review 82, 74-81.

Oh, J., Rhee, S.-K., 2008. The influence of supplier capabilities and technology uncertainty on manufacturer-supplier collaboration: A study of the Korean automotive industry. International Journal of Operations \& Production Management 28, 490-517.

Oliveira, J.S., Cadogan, J.W., Souchon, A., 2012. Level of analysis in export performance research. International Marketing Review 29, 114-127.

Pfeffer, J., Salancik, G.R., 2003. The external control of organizations: A resource dependence perspective. Stanford University Press, Stanford, CA.

Phan, K.N., Ghantous, N., 2013. Managing brand associations to drive customers' trust and loyalty in Vietnamese banking. The International Journal of Bank Marketing 31, 456-480.

Podsakoff, P.M., macKenzie, S.B., Lee, J.-Y., 2003. Common method bias in behavioral research: A critical review of the literature and recommended remedies. Journal of applied psychology 88 , 879-903.

Prashantham, S., Birkinshaw, J., 2008. Dancing with gorillas: How small companies can partner effectively with MNCs. California Management Review 51, 6-23.

Raisch, S., Birkinshaw, J., 2008. Organizational ambidexterity: Antecedents, outcomes, and moderators. Journal of Management 34, 375-409.

Raisch, S., Birkinshaw, J., Probst, G., Tushman, M.L., 2009. Organizational ambidexterity: Balancing exploitation and exploration for sustained performance. Organization Science 20, 685-695. 
Raman, R., Chadee, D., Roxas, B., Michailova, S., 2013. Effects of partnership quality, talent management, and global mindset on performance of offshore IT service providers in India. Journal of International Management 19, 333-346.

Reinartz, W., Haenlein, M., Henseler, J., 2009. An empirical comparison of the efficacy of covariance-based and variance-based SEM. International Journal of Research in Marketing 26, 332-344.

Shin, N., Kraemer, K.L., Dedrick, J., 2012. Value capture in the global electronics industry: Empirical evidence for the "smiling curve" concept. Industry and Innovation 19, 89-107.

Shirokova, G., Vega, G., Sokolova, L., 2013. Performance of Russian SMEs: Exploration, exploitation and strategic entrepreneurship. Critical Perspectives on International Business 9, 173-203.

Simsek, Z., Heavey, C., 2011. The mediating role of knowledge-based capital for corporate entrepreneurship effects on performance: A study of small-to medium-sized firms. Strategic Entrepreneurship Journal 5, 81-100.

Sirén, C.A., Kohtamäki, M., Kuckertz, A., 2012. Exploration and exploitation strategies, profit performance, and the mediating role of strategic learning: Escaping the exploitation trap. Strategic Entrepreneurship Journal 6, 18-41.

Song, M., Nason, R.W., Di Benedetto, C.A., 2008. Distinctive marketing and information technology capabilities and strategic types: A cross-national investigation. Journal of International Marketing 16, 4-38.

Speckbacher, G., Neumann, K., Hoffmann, W.H., 2015. Resource relatedness and the mode of entry into new businesses: Internal resource accumulation vs. access by collaborative arrangement. Strategic Management Journal 36, 1675-1687.

Stettner, U., Lavie, D., 2014. Ambidexterity under scrutiny: Exploration and exploitation via internal organization, alliances, and acquisitions. Strategic Management Journal 35, 1903-1929.

Su, F., Mao, J.Y., Jarvenpaa, S.L., 2014. How do IT outsourcing vendors respond to shocks in client demand? A resource dependence perspective. Journal of Information Technology 29, 253267.

Teece, D.J., 2014. The foundations of enterprise performance: Dynamic and ordinary capabilities in an (economic) theory of firms. The Academy of Management Perspectives 28, 328-352.

Touboulic, A., Chicksand, D., Walker, H., 2014. Managing imbalanced supply chain relationships for sustainability: A power perspective. Decision Sciences 45, 577-619.

Tourangeau, R., Rips, L.J., Rasinski, K., 2000. The psychology of survey response. Cambridge University Press.

Vandaie, R., Zaheer, A., 2014. Surviving bear hugs: Firm capability, large partner alliances, and growth. Strategic Management Journal 35, 566-577.

Vixathep, S., Matsunaga, N., 2012. Firm performance in a transitional economy: A case study of Vietnam's garment industry. Journal of the Asia Pacific Economy 17, 74-93.

Vorhies, D.W., Morgan, R.E., Autry, C.W., 2009. Product-market strategy and the marketing capabilities of the firm: Impact on market effectiveness and cash flow performance. Strategic Management Journal 30, 1310-1334.

Wall, T.D., Michie, J., Patterson, M., Wood, S.J., Sheehan, M., Clegg, C.W., West, M., 2004. On the validity of subjective measures of company performance. Personnel Psychology 57, 95-118.

Wathne, K.H., Heide, J.B., 2000. Opportunism in interfirm relationships: Forms, outcomes, and solutions. Journal of Marketing 64, 36-51.

Weerawardena, J., 2003. The role of marketing capability in innovation-based competitive strategy. Journal of Strategic Marketing 11, 15-35.

Williams, L.J., Hartman, N., Cavazotte, F., 2010. Method variance and marker variables: A review and comprehensive CFA marker technique. Organizational Research Methods 13, 477-514.

WTO, 2011. Trade patterns and global value chains in East Asia: from trade in goods to trade in tasks, in: Escaith, H., Inomata, S., Degain, C., Kenkyūjo, A.K. (Eds.). World Trade Organization, Geneva.

Xiao, J.H., Xie, K., Hu, Q., 2013. Inter-firm IT governance in power-imbalanced buyer-supplier dyads: Exploring how it works and why it lasts. European Journal of Information Systems 22, 512-528. 
Yu, Y., Sharma, R.R., 2016. Dancing with the stars: What do foreign firms get from high-status local partners? Management Decision 54, 1294-1319.

Zhao, X., Lynch Jr, J.G., Chen, Q., 2010. Reconsidering Baron and Kenny: Myths and truths about mediation analysis. Journal of Consumer Research 37, 197-206.

Zimmermann, A., Raisch, S., Birkinshaw, J., 2015. How is ambidexterity initiated? The emergent charter definition process. Organization Science 26, 1119-1139.

Zou, S., Fang, E., Zhao, S., 2003. The effect of export marketing capabilities on export performance: An investigation of Chinese exporters. Journal of International Marketing 11, 32-55. 
Figure 1. Theoretical model: capitalizing the exploitation strategy

\begin{tabular}{|c|c|c|}
\hline \multirow{3}{*}{$\begin{array}{l}\text { Exploitation Strategy } \\
\text { Dependency relationship } \\
\text { Lack of autonomy } \\
\text { Weaker power } \\
\text { Stable meager earnings }\end{array}$} & $\begin{array}{l}\text { Bilateral Tactics } \\
\text { Restructuring activities } \\
\text { Interaction with the powerful party }\end{array}$ & \multirow[b]{2}{*}{$\begin{array}{l}\text { Resource Transformation } \\
\text { Internal resource base } \\
\text { Related capabilities }\end{array}$} \\
\hline & \begin{tabular}{|l|} 
Resource dependency \\
Hard to get consent \\
\end{tabular} & \\
\hline & \multirow{2}{*}{$\begin{array}{l}\text { Unilateral Tactics } \\
\text { Shift in strategic direction } \\
\text { Entrepreneurial activities } \\
\text { Dual strategy } \\
\text { Preferred by CMEs }\end{array}$} & \\
\hline & & Enhanced Performance \\
\hline
\end{tabular}


Figure 2. The structural models

Figure 2a. The direct effects of exploitation strategy

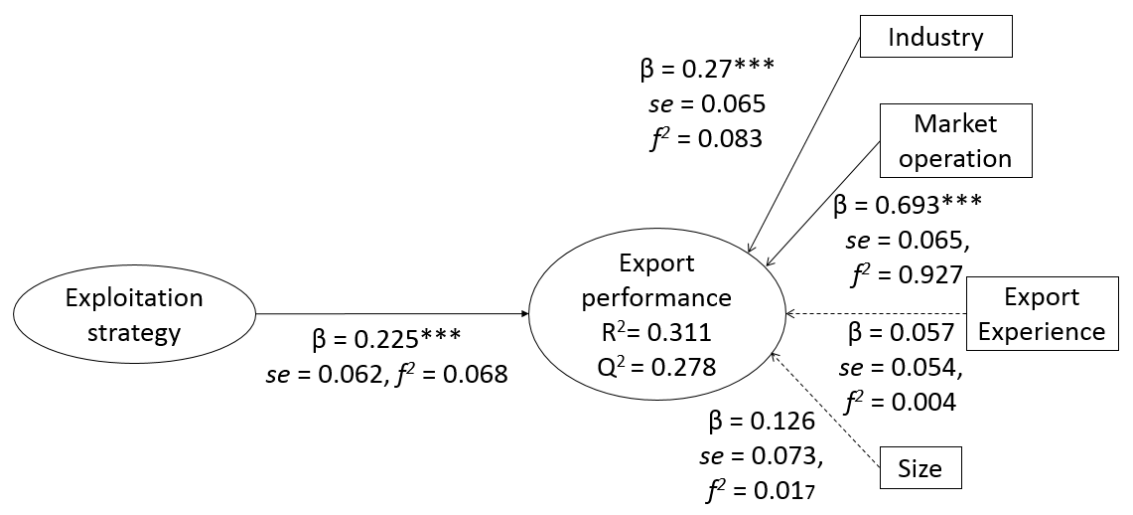

Figure $2 b$. The mediation effects of exploration strategy

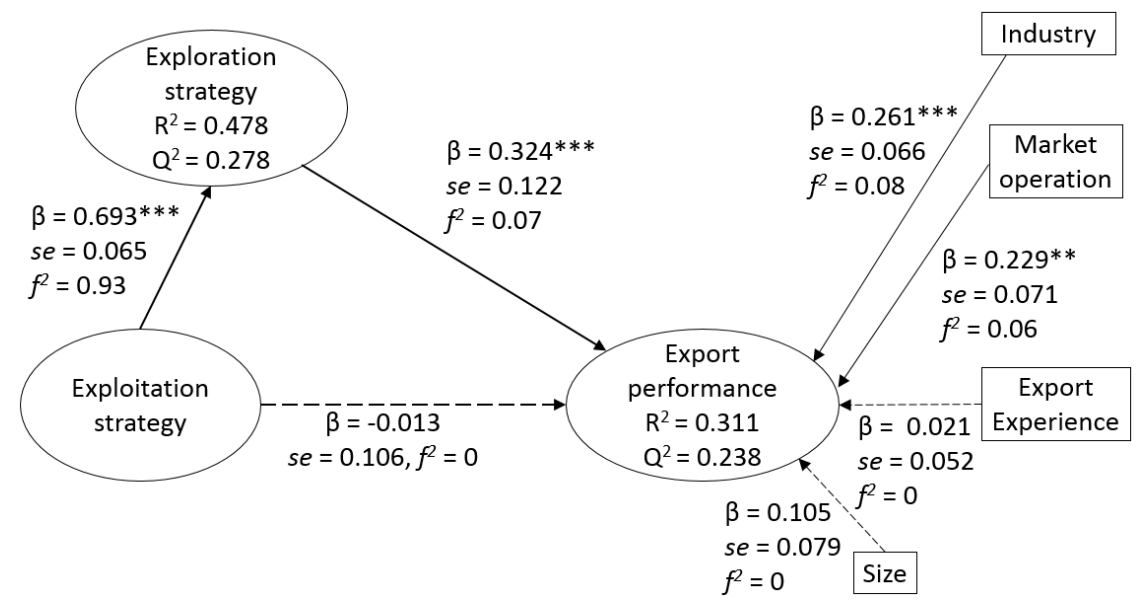

Figure 2c. The mediation effects of exploration strategy and marketing capability

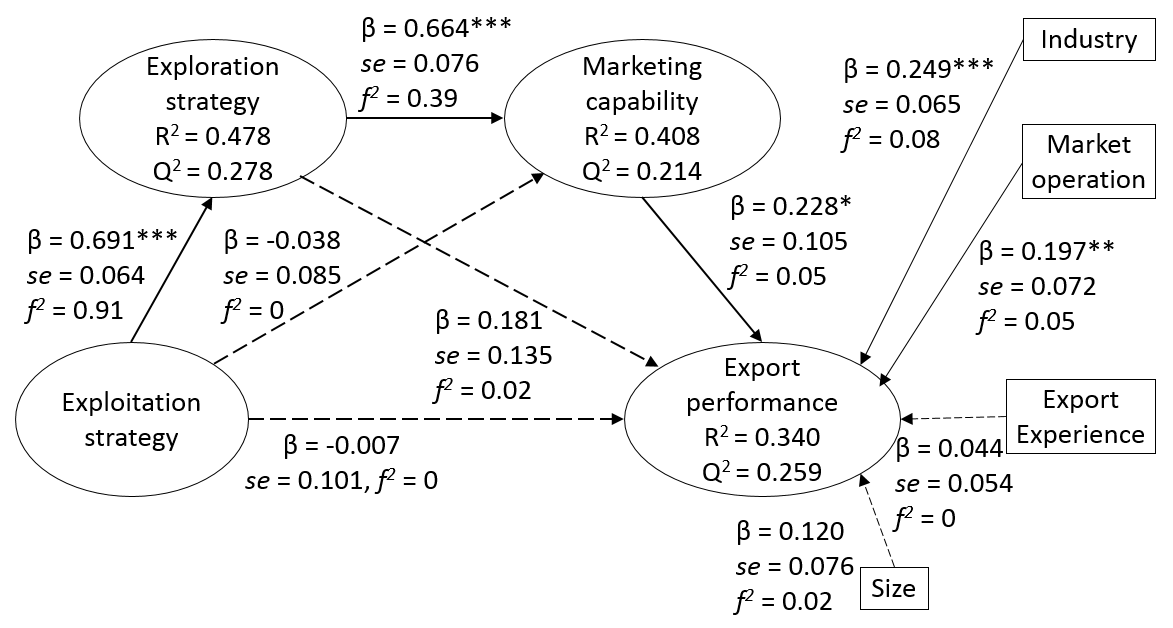


Table 1. The measurement model

\begin{tabular}{|c|c|c|c|}
\hline Indicator & $\begin{array}{c}\text { Factor } \\
\text { Loading }\end{array}$ & $\begin{array}{l}\text { Comun } \\
\text { ality* }\end{array}$ & $\begin{array}{c}\mathrm{T} \\
\text { value }\end{array}$ \\
\hline \multicolumn{4}{|l|}{$\begin{array}{l}\text { Export performance }\left(\alpha=0.927 ; \text { AVE }=0.82 ; \rho_{c}=0.948\right) \\
(7 \text { point scale } 1=\text { very low, } 7=\text { very high })\end{array}$} \\
\hline Export sales volume & 0.886 & 0.785 & $29.504 * * *$ \\
\hline Export sales growth & 0.944 & 0.891 & $76.216 * * *$ \\
\hline Export profitability & 0.910 & 0.828 & $38.010 * * *$ \\
\hline Export sales intensity & 0.880 & 0.774 & $29.195 * * *$ \\
\hline \multicolumn{4}{|l|}{$\begin{array}{l}\text { Exploitation strategy }\left(\alpha=0.761 ; A V E=0.510 ; \rho_{c}=0.838\right) \\
(5 \text { point scale } 1=\text { strongly disagree, } 5=\text { strongly agree })\end{array}$} \\
\hline Committing to improve quality and lower cost & 0.695 & 0.483 & $10.314 * * *$ \\
\hline Continuously improving the reliability of its products and services & 0.775 & 0.601 & $14.222 * * *$ \\
\hline Constantly surveying existing customers' satisfaction & 0.784 & 0.615 & $14.436 * * *$ \\
\hline Fine-tuning its offers to keep current customers satisfied & 0.639 & 0.408 & $5.454 * * *$ \\
\hline Penetrating more deeply into the existing customer base & 0.668 & 0.446 & $9.378 * * *$ \\
\hline \multicolumn{4}{|l|}{$\begin{array}{l}\text { Exploration strategy }\left(\alpha=0.768 ; A V E=0.590 ; \rho_{c}=0.852\right. \\
(5 \text { point scale } 1=\text { strongly disagree, } 5=\text { strongly agree })\end{array}$} \\
\hline Looking for novel technological ideas by thinking 'outside the box' & 0.801 & 0.642 & $20.587 * * *$ \\
\hline Creating products and services that are innovative to the firm & 0.732 & 0.536 & $13.286 * * *$ \\
\hline Looking for creative ways to satisfy customer's' needs & 0.770 & 0.593 & $17.876^{* * *}$ \\
\hline Aggressively venturing into new markets & 0.768 & 0.590 & $20.211 * * *$ \\
\hline \multicolumn{4}{|l|}{$\begin{array}{l}\text { Marketing capability }\left(\alpha=0.829 ; A V E=0.544 ; \rho_{c}=0.876\right) \\
(5 \text { point scale } 1=\text { much worse, } 5=\text { much better than competitors })\end{array}$} \\
\hline Knowledge of competitors & 0.806 & 0.650 & $26.414 * * *$ \\
\hline Knowledge of customers & 0.608 & 0.370 & $8.644 * * *$ \\
\hline Skills to segment and target markets & 0.678 & 0.460 & $12.188 * * *$ \\
\hline Effectiveness of pricing programs & 0.750 & 0.563 & $20.464 * * *$ \\
\hline Effectiveness of advertising programs & 0.676 & 0.457 & $11.812 * * *$ \\
\hline Control and evaluation of marketing activities & 0.874 & 0.764 & $39.838 * * *$ \\
\hline
\end{tabular}

$\alpha$ : Cronbach's alpha, $A V E$ : average variance extracted, $\rho_{c}$ : composite reliability, ${ }^{* * *} p \leq 0.001,{ }^{* *} p \leq 0.01$, and ${ }^{*} p \leq 0.05$ 
Table 2. Descriptive statistics, correlations, and means

\begin{tabular}{|c|c|c|c|c|c|c|c|c|c|c|c|c|}
\hline Construct & Mean & S.D. & Min & Max & 1 & 2 & 3 & 4 & 5 & 6 & 7 & 8 \\
\hline 1. Export performance & 5.312 & 1.285 & 1 & 7 & 0.905 & & & & & & & \\
\hline 2. Exploitation strategy & 4.456 & 0.601 & 1.80 & 5 & $0.248 * *$ & 0.714 & & & & & & \\
\hline 3. Exploration strategy & 4.320 & 0.734 & 1.75 & 5 & $0.419 * * *$ & $0.691 * * *$ & 0.768 & & & & & \\
\hline 4. Marketing capability & 3.624 & 0.566 & 2 & 5 & $0.432 * * *$ & $0.421 * * *$ & $0.638 * * *$ & 0.737 & & & & \\
\hline 5. Industry & 0.545 & 0.498 & 0 & 1 & $0.324 * * *$ & 0.041 & 0.097 & 0.098 & 1 & & & \\
\hline 6. Market operation & 0.792 & 0.406 & 0 & 1 & $0.315 * * *$ & 0.085 & $0.305 * * *$ & $0.332 * * *$ & -0.018 & 1 & & \\
\hline 7. Size $(n=140)$ & 0.657 & 0.475 & 0 & 1 & $0.215^{* *}$ & 0.037 & 0.063 & 0.019 & $0.394 * * *$ & -0.034 & 1 & \\
\hline 8. Export experience $(n=144)$ & 0.778 & 0.416 & 0 & 1 & 0.035 & -0.066 & -0.123 & 0.013 & $0.19 *$ & 0.078 & $0.284 * * *$ & 1 \\
\hline
\end{tabular}

Notes: $\quad$ Sample size $n=154$, specified otherwise

Pearson two-tailed correlations with significant levels at $* * * p<.001, * * p<.01, * p<.05$

Numbers along the diagonal indicate square roots of the variance extracted of each construct

Table 3. Analysis of mediation effects from partial least squares analysis

\begin{tabular}{|c|c|c|c|c|}
\hline \multirow[t]{2}{*}{ Mediation effect } & \multicolumn{2}{|c|}{ Model 2 (Figure 2b) } & \multicolumn{2}{|r|}{ Model 3 (Figure 2c) } \\
\hline & $\beta$ & $\mathrm{t}$ value & $\beta$ & Confidence Intervals \\
\hline L - R - EPERF & $0.225^{*}$ & 2.533 & 0.125 & CI 95\% $\quad[-0.057 ; 0.322]$ \\
\hline R - MARK - EPERF (H3) & & & $0.151 *$ & CI 95\% $\quad[0.012 ; 0.230]$ \\
\hline L - R - MARK - EPERF (H4) & & & $0.105^{*}$ & CI 95\% [0.008; 0.221$]$ \\
\hline
\end{tabular}

Notes: $\mathrm{L}=$ Exploitation strategy, $\mathrm{R}=$ Exploration strategy, MARK = Marketing capability, EPERF = Export performance

Confidence intervals are estimated with the bias-corrected bootstrap of 5,000 resamples

Significance levels at ***p $<0.001, * * p<0.01, * \mathrm{p}<0.05$ 
Table 4. Illustrative quotes from interviews with CMEs

\section{Exploitation strategy, exploration strategy and performance}

Exploitation strategy: C7: The processing work helps us exploit our capacity and maintain stable earnings. C10: Our pricing covers all the cost, but allows us a very small margin.

Exploration strategy: C1: Our core business has been men's suits shirts. But now we've shifted toward women. Profits from women's products are high due to short fashion cycles. C5: I think that we would have not made this much profit if we had not gone into FOB.

\section{Exploitation strategy, exploration strategy and capability development}

Poor earnings: C8: The main challenge is low profits, because we can only earn from labor work.

Low power: C7: We depend on buyers in several aspects. We need to follow their specifications strictly. When they tell us where to get the materials, we need to go to that place, and no others. $\mathrm{C} 1$ : They know our costs and our margins.

Entrepreneurial behavior: $\mathrm{C} 1$ : He (the VP referring to the CEO) is very proactive and wants us to do the ODM. C3: He is like a pioneer who shapes the strategy and leads us this way. C7: I realized that the designing, product development, and advertising are core capabilities of our buyers. After I figured it out, I think we can do it. C5: We were making small profits on the production. Until 2003, we realized that we were working for others, helping others become rich while we only earned enough for our living and could rarely save up any money for ourselves. C4: We earned little from CMT while we can have a little bit more on the materials with FOB. C6: The domestic market also has a potential.

Capabilities development: C2: Then she took me to Hong Kong with her and later to the head-quarters in the United States. I observed their system and talked to retailers and wholesalers there. After talking to them, I understand what they expect from their manufacturers. I tried to understand how they do their business and later on I could talk with them in their 'language'. C3: ABC is our own brand. So we need to do it ourselves. We set up our own system. We are well prepared regarding the production capability. But we have to build up our own marketing abilities. No one helps us on that function. We need to build a program to train our staff to serve customers in our way. It largely depends on the manager. C1: We develop skills gradually, to a certain level, we could take FOB orders. C9: We had more than ten years doing processing work. This time can be viewed as the training time for us to know how to do the job.

Notes: CMT: Cut-Make-Trim, referring to CMEs providing assembly service; FOB: Free on Board, referring to CMEs providing full-package service; ODM: Original Design Manufacturing, referring to CMEs providing owned-designed products; OBM: Original Brand name Manufacturing, referring to CMEs selling own-branded products 